\title{
PENGARUH KONSENTRASI ETANOL TERHADAP AKTIVITAS ANTIOKSIDAN EKSTRAK DAUN RAMBUSA (Passiflora foetida L.) MENGGUNAKAN METODE ULTRASONIC ASSISTED EXTRACTION (UAE)
}

The Effect of Ethanol Concentration of Antioxidant Activity Rambusa Leaves Extract (Passiflora foetida L.) with Ultrasonic Assisted Extraction (UAE).

${ }^{1}$ I Made Ananta Divasti Guna, ${ }^{2}$ I Nengah Kencana Putra*, ${ }^{2}$ A. A. I. Sri Wiadnyani

${ }^{1}$ Mahasiswa Program Studi Ilmu dan Teknologi Pangan, Fakultas Teknologi Pertanian, Universitas Udayana ${ }^{2}$ Dosen Program Studi Ilmu dan Teknologi Pangan, Fakultas Teknologi Pertanian, Universitas Udayana Kampus Bukit Jimbaran, Badung-Bali

\section{ABSTRACT}

This study was conducted to determine the effect of ethanol concentration on antioxidant activity and to obtain the highest antioxidant activity in rambusa leaves extract using the UAE method. The experimental design used in this study was a completely randomized design (CRD) with an ethanol concentration treatment consisting of five levels, namely $50 \%, 60 \%, 70 \%, 80 \%$, and $90 \%$. All treatments were repeated three times to obtain 15 experimental units. The data obtained were analyzed by the analysis of variance (ANOVA) and if the treatment had a significant effect, then followed by the Duncan test. The results showed that ethanol concentration had a significant effect on yield, total phenol, total flavonoids, total tannins, and antioxidant activity. The results showed that the treatment of $70 \%$ ethanol concentration was the best. The treatment produced the extract with a yield of $25,14 \%$, total phenol of $40,94 \mathrm{mg}$ GAE/g extract, total flavonoids of $38,95 \mathrm{mg}$ QE/g, total tannin of $33,49 \mathrm{mg} \mathrm{TAE} / \mathrm{g}$, the antioxidant activity based on free radical inhibition percentage of 70,58\%, and IC50 values of $328.20 \mathrm{mg} / \mathrm{L}$.

Keywords: antioxidant activity, ethanol, rambusa leaves, UAE,

\section{PENDAHULUAN}

Daun Rambusa (Passiflora foetida L.) merupakan tanaman yang tumbuh di daerah tropis, dan sering ditemukan merambat pada tanaman lainnya. Tanaman ini dapat dimanfaatkan sebagai teh herbal, sup serta buahnya dapat dikonsumsi saat sudah matang walaupun masih terbatas penggunaannya (Lim, 2012). Daun rambusa memiliki komposisi senyawa fitokimia utama meliputi alkaloid, fenolik, flavonoid yang dapat berfungsi sebagai antioksidan.

Potensi senyawa flavonoid sebagai antioksidan disebabkan gugus hidroksil dari senyawa tersebut terikat pada cincin karbon aromatic yang berfungsi sebagai antioksidan (Dhawan et al., 2004). Hasil penelitian Ajane dan Patil. (2019), melaporkan bahwa ekstrak daun rambusa menghasilkan total flavonoid 25,03 mg QE/g. Hasil penelitian Asir et al., (2014) juga melaporkan total kandungan fenolik dan flavonoid pada daun rambusa (Passiflora foetida L), dapat menurunkan peroksidasi lipid dan aktivitas radikal bebas. sehingga dapat menangkap radikal bebas yang dihasilkan dari reaksi peroksidasi lemak (Dewi et al., 2014).

Komponen bioaktif seperti antioksidan, fenolik, flavonoid dan tanin daun rambusa dapat diperoleh melalui tahap ekstraksi. Metode ekstraksi dapat dilakukan dengan berbagai cara, seperti ultrasonik, soxlet dan maserasi. Ekstraksi daun rambusa dapat dilakukan dengan metode ekstraksi gelombang ultrasonik. Keunggulan metode ekstraksi gelombang ultrasonik adalah lebih aman, lebih singkat, dan meningkatkan jumlah rendemen kasar.

Penelitian Kuldiloke (2002), melaporkan ekstraksi menggunakan bantuan gelombang ultrasonik meningkatkan rendemen ekstrak dibandingkan dengan metode ekstraksi konvensional seperti maserasi. Prinsip kerja ekstraksi menggunakan gelombang ultrasonik yaitu sifat akustik yang dirambatkan melalui medium yang dilewati. Pada saat gelombang 
merambat, medium yang dilewatinya akan mengalami getaran. Getaran tersebut memberikan pengadukan yang intensif pada proses ekstraksi. Pengadukan akan meningkatkan osmosis antara bahan dengan pelarut sehingga akan meningkatkan proses ekstraksi.

Jenis pelarut dan perbedaan konsentrasi pelarut mempengaruhi laju ekstraksi. Jenis pelarut yang digunakan pada proses ekstraksi harus memiliki tingkat kepolaran yang sejenis dengan senyawa yang diidentifikasi. Pelarut etanol memiliki karakteristik polar yang dapat digunakan dalam mengidentifikasi senyawa flavonoid (Arifin et al., 2006). Penelitian Asir et al. (2014) melaporkan ekstrak etanol daun rambusa menghasilkan jumlah flavonoid, dan fenolik yang optimal dibandingkan ekstrak daun rambusa menggunakan pelarut petrolium ether, kloroform, etil asetat. Semakin tinggi konsentrasi etanol semakin rendah tingkat kepolaran pelarut tersebut (Shadami, 2004).

Perbedaan konsentrasi etanol dapat mengakibatkan perubahan polaritas pelarut sehingga mempengaruhi kelarutan senyawa bioaktif (Zhang et al., 2009). Penelitian Prayitno et al., (2018) melaporkan hasil ekstrak daun sirih merah menggunakan pelarut etanol $50 \%$ dengan metode ekstraksi mikrowave menghasilkan IC50 yaitu 132,52 ppm. Penelitin Luginda et al., (2018) melaporkan hasil ekstrak daun beluntas menggunakan pelarut etanol $60 \%$ dengan metode ekstraksi mikrowave menghasilkan kadar flavonoid tertinggi sebesar $2,81 \%$. Penelitian lain dalam Widarta dan Arnata., (2017), melaporkan hasil ekstrak daun alpukat menggunakan pelarut etanol $70 \%$ dengan metode ekstraksi ultrasonik menghasilkan kadar total fenolik, flavonoid, tanin dan aktivitas antioksidan terbaik masing-masing yaitu 23,28 mg/g bahan, 93,97 mg/g bahan, 9,47 mg/g bahan dan 90,80\%. Penelitian Arista., (2013) melaporkan bahwa hasil ekstrak daun katuk menggunakan pelarut etanol $80 \%$ dengan metode ekstraksi maserasi kinetik menghasilkan nilai IC50 813,09 ppm.

\section{METODE PENELITIAN}

\section{Tempat dan Waktu}

Penelitian ini dilaksanakan di Laboratorium Analisis Pangan, Laboratorium Pengolahan Pangan Jurusan Ilmu dan Teknologi Pangan Fakultas Teknologi Pertanian, dan Laboratorium Biosains, Universitas Udayana. Pelaksanaan penelitian ini dilakukan pada bulan Agustus 2019 sampai dengan bulan Oktober 2019.

\section{Bahan dan Alat}

Bahan yang digunakan dalam penelitian ini terdiri dari bahan baku dan bahan kimia. Bahan yang digunakan dalam penelitian ini adalah daun rambusa (Passiflora foetida L.) yang diperoleh di Bukit Jimbaran, Bali. Bahan kimia yang dipergunakan terdiri dari aquades, etanol PA (Merck), reagen FolinCiocalteau (Merck), reagen Folin Denis (Merck), $\mathrm{Na}_{2} \mathrm{CO}_{3}$ (Merck), $\mathrm{NaNO}_{2}$ (Merck), $\mathrm{AlCl}_{3}$ (Merck), NaOH 1M (Merck), air es, asam galat (Sigma), kuersetin (Sigma), asam tanat (Sigma) dan 1,1-diphenyl-2picrylhydrazil (DPPH) (Sigma), Air es.

Alat-alat Alat yang digunakan dalam penelitian ini terdiri dari botol sampel, aluminium foil, kertas saring Whatman No. 1, rotary vacuum evaporator (IKA Labortechnik), pipet volume (pyrex), timbangan analitik (sartorius), spektrofotometer UV-VIS (Biochrom Libra), pipet tetes, beaker glass (pyrex), vortex, gelas ukur (pyrex), erlenmeyer (pyrex), labu ukur (pyrex), spatula, corong kaca (pyrex), ultrasonic bath (Branson 2002), cawan porselen, blender (Philips), oven (Labo DO 225), loyang, water bath, tabung reaksi (pyrex), rak tabung reaksi, kuvet, ayakan 60 mesh (Retsch), dan kertas label. dan alumunium foil. 


\section{Pelaksanaan Penelitian Persiapan Sampel}

Daun rambusa yang telah dipersiapkan selanjutnya disortasi, dicuci bersih dengan air mengalir, dan ditiriskan. Daun yang dipilih merupakan daun yang berwarna hijau muda, berada pada bagian tengah batang hingga pucuk teratas, berukuran sedang, dan tidak memiliki bitnik-bintik kuning atau putih di permukaannya.

Daun rambusa selanjutnya dikeringkan dengan oven pada suhu $50^{\circ} \mathrm{C}$ selama 3 jam 30 menit (hingga kandungan kadar air $\leq 10 \%$, dengan kriteria daun berwarna hijau pudar dibanding keadaan segar dan mudah hancur ketika diremas). Daun rambusa yang terlah kering kemudian dihaluskan menggunakan blender kemudian diayak dengan ayakan 60 mesh (Hendryani et al., (2015) yang telah dimodifikasi).

\section{Pembuatan Ekstrak Sampel}

Pembuatan Ekstraksi Bubuk daun rambusa ditimbang sebanyak 15 gram menggunakan timbangan analitik, dimasukkan ke dalam Erlenmeyer. Ditambahkan pelarut etanol dengan perlakuan konsentrasi 50\%, 60\%, 70\%, 80\%, dan 90\% sebanyak $150 \mathrm{ml}(1: 10 \mathrm{~b} / \mathrm{v})$, kemudian diekstraksi dengan suhu $45^{\circ} \mathrm{C}$ selama 20 menit menggunakan ultrasonic bath.

Bubuk daun rambusa yang telah diekstraksi dengan ultrasonic bath kemudian disaring menggunakan kertas whatman no.1. Filtrat yang diperoleh selanjutnya dilakukan evaporasi Evaporasi dilakukan dengan rotary vacuum evaporator dengan tekanan $100 \mathrm{mbar}$, suhu $40{ }^{\circ} \mathrm{C}$ dan putaran $100 \mathrm{rpm}$. Ekstrak kental yang diperoleh ditimbang dan dihitung rendemen ekstraknya (Hendryani et al., 2015 yang telah dimodifikasi).

\section{Rancangan Penelitian dan Analisis Data}

Penelitian Penelitian Penelitian ini menggunakan RAL (Rancangan Acak Lengkap) dengan perlakuan konsentrasi pelarut etanol dengan 5 taraf yaitu:

K1: Konsentrasi Etanol 50\%

K2: Konsentrasi Etanol 60\%

K3: Konsentrasi Etanol 70\%

K4: Konsentrasi Etanol 80\%

K5: Konsentrasi Etanol 90\%

Masing-masing perlakuan diulang sebanyak tiga kali sehingga diperoleh 15 unit percobaan. Data yang diperoleh pada penelitian ini selanjutnya dianalisis dengan sidik ragam atau Analysis of Variance (ANOVA), apabila perlakuan berpengaruh nyata akan dilanjutkan dengan uji Duncan (Steel dan Torrie, 1993).

\section{Parameter yang Diamati}

Parameter yang diamati dalam penelitian ini meliputi rendemen (AOAC, 1999), total fenol (Garcia et al., 2007), total flavonoid (Xu dan Chang 2007), total tanin (Rajan et al.,2011) dan aktivitas antioksidan (Mosquera et al.,2009).

\section{HASIL DAN PEMBAHASAN}

Hasil analisis rendemen, total fenol, total flavonoid, total tanin dan aktivitas antioksidan ekstrak daun rambusa dapat dilihat pada tabel 1 .

\section{Rendemen Ekstrak}

Nilai Hasil sidik ragam menunjukan bahwa konsentrasi etanol pada ekstrak daun rambusa berpengaruh nyata $(\mathrm{P}<0,05)$ terhadap rendemen ekstrak daun rambusa. Berdasarkan Tabel 1, rendemen terendah terdapat pada konsentrasi etanol 90\% (K5) yaitu $11,93 \%$. Rendemen ekstrak daun rambusa tertinggi yaitu pada konsentrasi etanol $70 \%$ (K3) yaitu $25,14 \%$. Hal tersebut diduga terjadi karena pelarut etanol $70 \%$ merupakan pelarut dengan tingkat kepolaran yang paling mendekati kepolaran senyawa- 
senyawa bioaktif pada daun rambusa. Menurut Prayoga, (2019) Semakin mirip kepolaran pelarut dengan kepolaran zat yang terkandung dalam bahan yang diekstraksi maka akan semakin banyak komponen zat yang dapat diekstraksi sehingga dapat terjadi peningkatan rendemen yang diperoleh.

Tabel 1 juga menunjukkan penurunan rendemen ekstrak daun rambusa pada perlakuan konsentrasi etanol di atas $70 \%$. Hal itu diduga karena penambahan etanol dengan konsentrasi di atas $70 \%$ menyebabkan polaritas pelarut menurun, dimana harborne (1973) menyatakan bahwa ekstraksi memiliki prinsip dasar like dissolves like yaitu kelarutan suatu senyawa pada pelarut didasari oleh kesamaan polaritas antara pelarut dengan senyawa yang diekstrak. Menurut Fatiha et al. (2012), jenis dan polaritas pelarut sangat mempengaruhi rendemen senyawa kimia yang dihasilkan.

Tabel 1. Nilai rata-rata rendemen, total fenolik, total flavonoid,total tanin, aktivitas antioksidan, dari ekstrak daun rambusa

\begin{tabular}{cccccc}
$\begin{array}{c}\text { Konsentrasi } \\
\text { Etanol } \\
(\%)\end{array}$ & Rendemen (\%) & $\begin{array}{c}\text { Total Fenol }(\mathrm{mg} \\
\text { GAE/g) }\end{array}$ & $\begin{array}{c}\text { Total Flavonoid } \\
(\mathrm{mg} \text { QE/g) }\end{array}$ & $\begin{array}{c}\text { Total Tanin }(\mathrm{mg} \\
\text { TAE/g) }\end{array}$ & $\begin{array}{c}\text { Aktivitas } \\
\text { Antioksidan } \\
(\%)\end{array}$ \\
\hline K1 ( 50 $)$ & $21,90 \pm 0,77 \mathrm{c}$ & $26,95 \pm 0,54 \mathrm{~d}$ & $28,47 \pm 2,85 \mathrm{c}$ & $21,73 \pm 1,49 \mathrm{c}$ & $58,94 \pm 0,38 \mathrm{c}$ \\
$\mathrm{K} 2(60)$ & $23,15 \pm 0,86 \mathrm{~b}$ & $36,48 \pm 0,83 \mathrm{~b}$ & $33,55 \pm 1,45 \mathrm{~b}$ & $27,94 \pm 1,96 \mathrm{~b}$ & $67,26 \pm 0,50 \mathrm{~b}$ \\
$\mathrm{~K} 3(70)$ & $25,14 \pm 0,59 \mathrm{a}$ & $40,94 \pm 1,74 \mathrm{a}$ & $38,95 \pm 1,90 \mathrm{a}$ & $33,49 \pm 2,46 \mathrm{a}$ & $70,58 \pm 0,79 \mathrm{a}$ \\
$\mathrm{K} 4(80)$ & $18,17 \pm 0,64 \mathrm{~d}$ & $30,56 \pm 0,64 \mathrm{c}$ & $23,07 \pm 1,98 \mathrm{~d}$ & $16,83 \pm 2,04 \mathrm{~d}$ & $55,88 \pm 0,66 \mathrm{~d}$ \\
$\mathrm{~K} 5(90)$ & $11,93 \pm 0,46 \mathrm{e}$ & $23,37 \pm 0,77 \mathrm{e}$ & $16,41 \pm 2,39 \mathrm{e}$ & $13,23 \pm 0,98 \mathrm{e}$ & $53,49 \pm 0,85 \mathrm{e}$ \\
\hline
\end{tabular}

Keterangan: Angka yang diikuti huruf yang berbeda dibelakang nilai rata-rata pada kolom yang sama menunjukkan perbedaan yang nyata dengan tingkat kepercayaan $95 \%(\mathrm{P}<0,05)$, Nilai rata-rata diikuti dengan \pm standar deviasi.

\section{Total Fenolik}

Hasil Hasil sidik ragam menunjukkan bahwa konsentrasi etanol berpengaruh nyata terhadap total fenolik ekstrak daun rambusa. Berdasarkan Tabel 1 dapat dilihat bahwa total fenolik tertinggi dihasilkan dari perlakuan konsentrasi etanol 70\% (K3) sebesar 40,94 mg GAE/g, sedangkan hasil paling rendah diperoleh dengan perlakuan konsentrasi etanol 90\% (K5) sebesar 23,37 mg GAE/g.

Berdasarkan Tabel 1 diketahui bahwa peningkatan total fenolik signifikan terjadi pada pelarut etanol konsentrasi $50 \%$ sampai $70 \%$. Hal tersebut diduga terjadi karena pelarut etanol $70 \%$ memiliki sifat kepolaran yang sangat mendekati kepolaran senyawasenyawa fenolik pada daun rambusa sehingga menghasilkan persentase total fenolik yang lebih tinggi dibanding pelarut etanol dengan konsentrasi lainnya. Hal sebaliknya terjadi pada total fenolik ekstrak daun rambusa dengan perlakuan etanol di atas $70 \%$ yang semakin mengalami penurunan. Hal tersebut mungkin disebabkan karena kepolaran etanol dengan konsentrasi di atas $70 \%$ semakin menurun dan menjauhi kepolaran senyawa fenolik daun rambusa, sehingga senyawa fenolik yang terekstrak akan semakin sedikit. Menurut Shadmani. (2004) semakin tinggi konsentrasi etanol maka semakin rendah tingkat kepolaran pelarutnya. Suatu zat akan larut dan terekstrak dengan baik apabila memiliki tingkat kepolaran yang sama dengan pelarut yang digunakan (Yuswi. 2017). Hal 
serupa dilaporkan oleh Widarta dan Arnata. (2017) pada daun alpukat dengan total fenolik tertinggi diperolah pada konsentrasi etanol 70 $\%$. Sementara itu, Prayoga. (2019) juga melaporkan bahwa pada daun pepe total fenolik tertinggi diperoleh pada konsentrasi etanol $70 \%$ yaitu 43,40 mg GAE/g ekstrak. Total fenolik pada penelitian ini relatif lebih besar jika dibandingkan dengan penelitian Setiawan., (2017) dengan total fenolik ekstrak daun papermint yaitu 28,96 mg GAE/g.

\section{Total Flavonoid}

Hasil analisis Hasil sidik ragam menunjukkan bahwa konsentrasi etanol berpengaruh nyata $(\mathrm{P}<0,05)$ terhadap total flavonoid ekstrak daun rambusa. Berdasarkan Tabel 1 dapat dilihat bahwa total flavonoid tertinggi dihasilkan pada perlakuan konsentrasi etanol 70\% (K3) yaitu 38,95 mg $\mathrm{QE} / \mathrm{g}$, sedangkan hasil paling rendah diperoleh dengan perlakuan konsentrasi etanol $90 \%$ (K5) yaitu 16,41 mg QE/g.

Berdasarkan Tabel 1 diketahui bahwa peningkatan total flavonoid signifikan terjadi pada perlakuan pelarut etanol konsentrasi 50 $\%$ sampai $70 \%$. Hal tersebut diduga terjadi karena perbedaan konsentrasi etanol dapat mengakibatkan perubahan polaritas pelarut sehingga mempengaruhi kelarutan senyawa bioaktif seperti flavonoid. Tabel 1 juga menunjukkan terjadinya penurunan total flavonoid yang terjadi seiring penambahan konsentrasi etanol di atas $70 \%$. Hal tersebut diduga terjadi karena penambahan konsentrasi etanol di atas $70 \%$ menyebabkan tingkat kepolaran pelarut etanol semakin menurun sehingga pengikatan senyawa flavonoid pada ekstrak daun rambusa tidak optimum akibat ketidaksesuaian tingkat kepolaran. Prayoga (2019) menyatakan bahwa umumnya flavonoid ditemukan berikatan dengan gula membentuk glikosida yang menyebabkan senyawanya lebih mudah larut dalam pelarut polar. Hal serupa juga dilaporkan oleh Zhang et al., (2009) yang menyatakan bahwa konsentrasi etanol $70 \%$ secara optimum dapat melarutkan senyawa flavonoid ekstrak daun lotus dibandingkan dengan konsentrasi etanol $65 \%$ dan $75 \%$.

Kadar total flavonoid ekstrak daun rambusa lebih tinggi dibandingkan kadar total flavonoid ekstrak daun papermint yaitu 12,42 mg QE/g (Setiawan et al., 2017). Kadar total flavonoid ekstrak daun rambusa pada penelitian ini juga lebih tinggi dibandingkan kadar total flavonoid 25,03 mg QE/g ekstrak daun rambusa yang juga diperoleh dari pelarut etanol (Ajane dan Patil., 2019).

\section{Total Tanin}

Hasil sidik ragam menunjukkan bahwa konsentrasi etanol berpengaruh nyata $(\mathrm{P}<$ $0,05)$ terhadap total tanin ekstrak daun rambusa. Berdasarkan Tabel 1 dapat dilihat bahwa total tanin tertinggi dihasilkan pada perlakuan konsentrasi etanol $70 \%$ (K3) yaitu 33,49 mg TAE/g sedangkan hasil paling rendah diperoleh dengan perlakuan konsentrasi etanol $90 \%$ (K5) yaitu 13,23 mg TAE/g. Tabel 1 menunjukkan bahwa kenaikan total tanin pada konsentrasi $50 \%$ hingga $70 \%$ mungkin dikarenakan seiring penambahan konsentrasi etanol mempengaruhi polaritas pelarut tersebut. Menurut Fengel dan Wegener. (1995) tanin merupakan senyawa makromolekul dari golongan polifenolik yang berisifat polar sehingga larut dalam pelarut polar.

Penurunan total tanin pada konsentrasi di atas $70 \%$ selaras dengan penurunan total flavonoid dan total fenolik yang disebabkan tingkat kepolaran pelarut semakin menurun. Kepolaran pelarut etanol tiap konsentrasi juga mempengaruhi tingkat kelarutan senyawa tanin sehingga total tanin yang dihasilkan akan berbeda. Menurut Stankovic et al., (2012), material tanaman mengandung senyawa fenolik yang bervariasi dari yang sederhana hingga terpolimerisasi seperti tanin dalam jumlah yang berbeda. 


\section{Aktivitas Antioksidan}

Hasil sidik ragam menunjukkan bahwa konsentrasi etanol berpengaruh nyata $(\mathrm{P}<0,05)$ terhadap aktivitas antioksidan ekstrak daun rambusa. Berdasarkan Tabel 1 dapat dilihat bahwa aktivitas antioksidan ekstrak daun rambusa tertinggi dihasilkan pada perlakuan konsentrasi etanol 70\% (K3) yaitu $70,58 \%$ sedangkan hasil paling rendah diperoleh dengan perlakuan konsentrasi etanol $90 \%$ (K5) yaitu 53,49\%.

Berdasarkan hasil analisis yang telah dilakukan, konsentrasi etanol $70 \%$ memberikan perlakuan yang terbaik berdasarkan nilai aktivitas antioksidan yang tinggi disertai dengan total flavonoid, total fenolik dan total tanin yang juga tinggi dibandingkan dengan perlakuan yang lain, sehingga perlakuan ini dipilih untuk pengujian IC50. Aktivitas antioksidan ekstrak daun rambusa mengalami peningkatan seiring dengan meningkatnya senyawa yang bersifat antioksidan seperti total fenolik, total flavonoid dan total tanin, tetapi pada konsentrasi etanol di atas $70 \%$ aktivitas antioksidan menurun selaras dengan penurunan senyawa yang bersifat antioksidan. Hal ini

dikarenakan konsentrasi etanol mengalami kondisi optimium dan tingkat kepolaran pada masing-masing konsentrasi yang berbeda sehingga mempengaruhi senyawa metabolit sekunder yang tersari saat proses ekstraksi

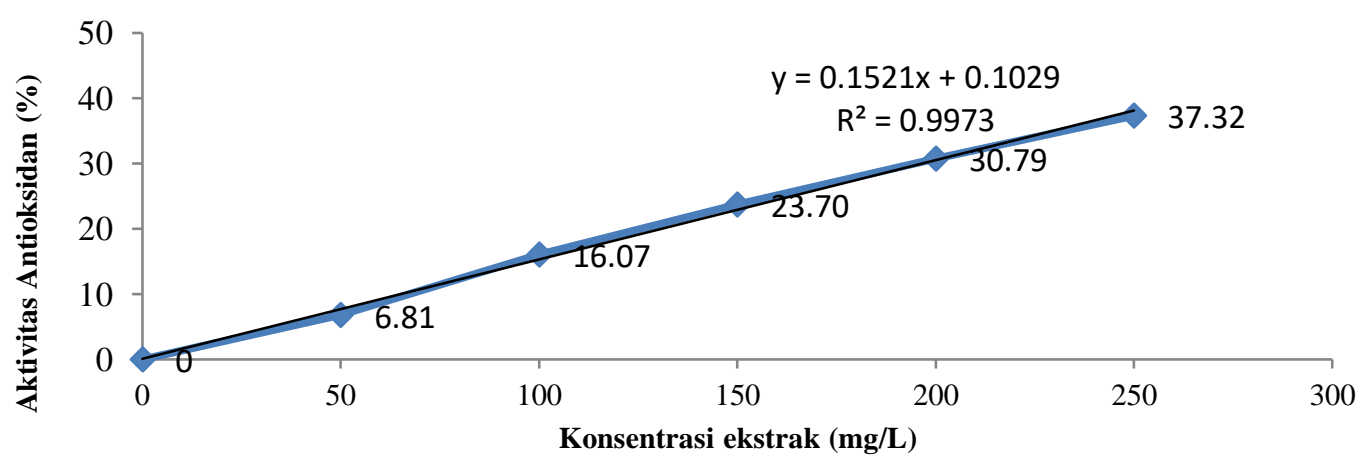

Gambar 1. Grafik hubungan antara aktivitas antioksidan dan konsentrasi ekstrak daun rambusa

Berdasarkan analisis regresi linier konsentrasi ekstrak daun rambusa menggunakan pelarut etanol $70 \%$ pada gambar 1 menunjukkan bahwa semakin tinggi konsentrasi ekstrak, aktivitas antioksidan yang dihasilkan akan mengalami peningkatan. Analisis regresi linier menghasilkan persamaan $\mathrm{y}=0,1521 \mathrm{x}+0,1029$ dengan IC50 $328,20 \mathrm{mg} / \mathrm{L}$. Menurut Blois (1958) suatu senyawa memiliki aktivitas antioksidan yang lemah apabila memiliki nilai IC50 > 200 $\mathrm{mg} / \mathrm{L}$, sehingga pada ekstrak daun rambusa dalam penelitian ini termasuk dalam kategori lemah.

Tabel 2. Nilai Koefisien Kolerasi antara total fenolik, total flavonoid dan total tanin dengan aktivitas antioksidan ekstrak daun rambusa.

\begin{tabular}{|l|l|}
\hline $\begin{array}{l}\text { Parameter Yang } \\
\text { Diuji }\end{array}$ & $\begin{array}{l}\text { Koefisien Korelasi } \\
\left(\mathrm{R}^{2}\right)\end{array}$ \\
\hline Total Eenolik & 0,8595 \\
\hline Total Flavonoid & 0,9345 \\
\hline Total Tanin & 0,9797 \\
\hline
\end{tabular}


Berdasarkan Tabel 2, Koefisien korelasi $\left(\mathrm{R}^{2}\right)$ antara total fenolik dengan aktivitas antioksidan ekstrak daun rambusa yaitu 0,8595, sementara koefisien korelasi $\left(\mathrm{R}^{2}\right)$ antara total flavonoid dengan aktivitas antioksidan ekstrak daun rambusa yaitu 0,9345, dan koefisien kolerasi $\left(\mathrm{R}^{2}\right)$ antara total tanin dengan aktivitas antioksidan ekstrak daun rambusa yaitu 0,9797. Sarwono (2006) menyatakan bahwa koefisien korelasi $\left(\mathrm{R}^{2}\right)$ yang mempunyai nilai 0,75 keatas dapat dikategorikan memiliki korelasi sangat kuat. Berdasarkan Tabel 2, nilai koefisien kolerasi $\left(\mathrm{R}^{2}\right)$ juga menunjukkan bahwa total tanin memperoleh nilai tertinggi yaitu 0,9797.

Senyawa fenolik termasuk flavonoid dan tanin dapat berperan sebagai antioksidan karena mengandung gugus hidroksil yang terikat pada karbon cincin aromatik sehingga dapat menangkap radikal bebas (Saxena et al., 2013). Senyawa fenolik juga dapat bereaksi dengan radikal bebas karena memiliki kemampuan mendonorkan elektron (reduktor) sehingga menghasilkan produk yang lebih stabil serta menghambat reaksi berantai radikal bebas (Plaza et al., 2014). Penelitian Asir et al., (2014) melaporkan bahwa total kandungan fenolik dan flavonoid yang terdapat pada ekstrak daun rambusa dapat menurunkan peroksidasi lipid dan aktivitas radikal bebas. Aktivitas antioksidan yang didapatkan pada masing-masing konsentrasi etanol selaras dengan total kadar flavonoid, fenolik, dan tannin. Hal ini menunjukan adanya hubungan antara total flavonoid, fenolik dan tanin yang diperoleh dari ekstrak daun rambusa dengan aktivitas antioksidan.

\section{KESIMPULAN DAN SARAN}

\section{Kesimpulan}

Berdasarkan hasil penelitian dapat disimpulkan hal-hal sebagai berikut:

1. Konsentrasi etanol berpengaruh sangat nyata terhadap rendemen, total fenolik, total flavonoid, total tanin dan aktivitas antioksidan ekstrak daun rambusa.
2. Hasil penelitian menunjukkan bahwa konsentasi etanol $70 \%$ mampu menghasilkan ekstrak daun rambusa yang memiliki aktivitas antioksidan tertinggi berdasarkan persentase penghambatan radikal yaitu $70,58 \%$ dengan nilai IC50 sebesar 328,20 mg/L, rendemen 25,14\%, total fenol 40,94 mg GAE/g ekstrak, total flavonoid 38,95 mg QE/g ekstrak dan total tanin 33,49 mg TAE/g ekstrak.

\section{Saran}

Berdasarkan hasil penelitian, disarankan menggunakan konsentrasi etanol $70 \%$ dalam melakukan proses ekstraksi pada bagian lain dari tanaman rambusa untuk memperoleh aktivitas antioksidan terbaik. Perlu dilakukan penelitian lebih lanjut terkait aplikasi ekstrak daun rambusa pada produk pangan

\section{DAFTAR PUSTAKA}

Ajane, G.A., A.S. Patil. 2019. Evaluation of antioxidant potential of Passiflora foetida extract and quantitative evaluation of its phytochemical content- a possible natural antioxidant. The Pharmaceutical and Chemical Journal. 6(4):14-24.

Albayrak, S., A. Bayram, dan A. Ahmet. 2017. Comparison of phenolic components and biogical activities of two Centaurea sp. Obtained by three extraction techniques. Asian Pasific Journal of Tropical Medicine. 10(6): 599-606.

AOAC. 1999. Official Method of Analysis of Association Official Agriculture Chemist Washington DC.

Arifin, H., N. Anggraini, D. Handayani dan R. Rasyid. 2006. Standarisasi ekstrak etanol daun Eugenia cumini Merr. Jurnal Sains Tek. Farmasi. 11(2):8893. 
Arista, M. 2013. Aktivitas antioksidan ekstrak etanol $80 \%$ dan $96 \%$ daun katuk (Sauropus androgynus (L.) Merr.) Jurnal Ilmiah Mahasiswa. Fakultas Farmasi, Universitas Surabaya. 2(2): 1-16.

Asir, P. J., S. Hemmalakshmi, S. Priyanga, dan K. Devaki. 2014. Antidiabetic activity of aqueous and ethanolic extracts of Passiflora foetida L. in alloxan induced diabetes rats. World journal of pharmaceutical research volume. 3:1627-164.

Asir, P. J., S. Hemmalakshmi, S. Priyanga, dan K. Devaki. 2014. In vitro free radical scavenging activity and secondary metabolites in passiflora foetidaL. World journal of pharmaceutical research volume. 6(2): 3-11.

Bimakr, M., R.A. Rahman, Taip, S.F.Adzahan, N.M., Sarker, I.Z. dan A. Ganjloo. 2013. Ultrasound-assisted extraction of valuable compounds from winter melon (Benincasa hispida) seeds. International Food Research Journal. 20: 331-338.

Blois, M.S. 1958. Antioxidant determinations by the use of a stable free radical. Nature. 181:1199-1200.

Dewi, N.W.O.A.C., N.M. Puspawati., I.M.D. Swantara., I.A.R.A. Asih. dan W.S. Rita. 2014. Aktivitas antioksidan senyawa flavonoid ekstrak etanol biji terong belanda (Solanum betaceum ) dalam menghambat reaksi peroksidasi lemak pada plasma darah tikus wistar. cakra kimia (Indonesian E- Journal of Applied Chemistry). 2(1): 7-16.

Dhawan, K., S. Dhawan, dan A. Sharma. 2004. Passiflora: a review update, J. Ethnopharmacol, 94: 1-23.
Fatiha B, M Khodir, D. Farid, R Tiziri, B Karima, O Sonia, C Mohamed. 2012. Optimisation of solvent extraction of antioxidants (phenolic compounds) from algerian mint (Mentha spicata L.). Pharmacognosy Communications 2(4):72-86.

Fengel D. dan Wegener G. 1995. Кауu: Kimia Ultrastruktur Reaksi-Reaksi. Gadjah Mada University Press, Yogyakarta.

Fu, L., B.T. Xu, R.Y. Gan, Y. Zhang, X.R. Xu, E. Xia, Li, Q.H.B. 2011. Total Phenolic Contens and Antioxidant Capicities of Herbal and Tea Infusion, Int. J. Mol. Sci. 12: 2112-2124.

Garcia, J.L.L, dan M.D.L. Castro. 2004. Ultrasound-assisted soxhlet extraction: an expeditive approach for solid sample treatment, application to the extraction of total fat from oleaginous seeds. Journal Chromatography A. 1034: 237242.

Garcia, C. A., G. Gavino, M.B. Mosqueda, P. Hevia, dan V.C. Gavino. 2007. Correlation of tocopherol, tokotrienol, $\gamma$-oryzanol and total polyphenol content in rice bran with different antioxidant capacity assays. Food Chemistry. 10(2): 1230-1232.

Harbone JB. 1987. Metode Fitokimia. Edisi ke-2. Padmawinata K, Soediro I, penerjemah. Bandung: Institut Teknologi Bandung. Terjemahan dari: Phytochemical Methods.

Hendryani, L., M. Lutfi, dan C. L. Hawa. 2015. Ekstraksi antioksidan daun sirih merah kering (Piper crotatum) dengan metode pra-perlakuan ultrasonic assisted extraction (kajian perbandingan jenis pelarut dan lama ekstraksi). Bioproses komoditas tropis. 3(2):33-35. 
Kuldiloke, J. 2002. EFFECT ULTRASOUND, TEMPERATURE, AND PRESSURE TREATMENT ON ENZYME ACTIVITY AND QUALITY INDICATORS OF FRUIT AND VEGETABLES JUICES. Desertasi S3. Tidak dipublikasikan. Universitas Berlin, Berlin.

Lim, T.K. 2012. Edible Medicinal dan NonMedicinal Plants Volume 4 Fruits . New York: Springer: 166-172.

Luginda, R. A., B. Lohita, dan L. Indriani. 2018. Pengaruh variasi konsentrasi pelarut etanol terhadap kadar flavonoid total daun beluntas (Pluchea indica (1.)Less) dengan metode microwaveassisted extraction (MAE). Program Studi Farmasi FMIPA. Universitas Pakuan. Bogor.

Mosquera, O.M., Y.M. Correa, dan J. Nino. 2009. Antioxidant activity of plants extract from Colombian flora Braz. J. Pharm. 19(2A): 382-387.

Patil, A.S., H.M. Paikrao, and S.R. Patil. 2013. Passiflora foetida Linn: A Complete Morphological and Phytopharmacological Review, International Journal of Pharma and Bio Sciences. 4(1): 285-296.

Plaza, C.M., L.E Diaz de Torres, R.K. Lucking, M. Vizcaya dan G.E. Medina. 2014. Antioxidant activity, total phenols and flavonoids of lichens from venezuelan andes. Journal of Pharmacy and Pharmacognosy Research 2:138147.

Prayoga, D.G.E., K.A. Nocianitri, dan N.N.Puspawati. 2019. Identifikasi senyawa fitokimia dan aktivitas antioksidan ekstrak kasar daun pepe (gymnema reticulatum br.) pada berbagai jenis pelarut. Jurnal Ilmu dan Teknologi Pangan. 8(2): 111-121.
Prayitno, S.A., J. Kusnadi, E.S. Murtini. 2018. Karakteristik (Total Flavonoid, Total Fenolik, Aktivitas Antioksidan) Ekstrak Serbuk Daun Sirih Merah (Piper crocatum Ruiz \& Pav.). Foodscitech. 1(5):26-34.

Rajan, S., S. Mahalakshmi, V. Deepa, K. Sathya, S. Shajitha, dan T. Thirunalasundari. 2011. Antioxidant potentials of punica granatum fruit rind extracts. International Journal of Pharmacy and Pharmaceutical Sciences 3:82-88.

Saxena, M., J. Saxena, D. Singh dan A. Gupta. 2013. Phytochemistry of medicinal plants. Journal of Pharmacognosy and Phytochemistry 1(6):168-182.

Setiawan, A., K. Bambang, dan S.Y. Elly. 2019. Ekstraksi daun peppermint (Mentha Piperita L.) menggunakan metode microwave assisted extraction terhadap total fenolik, tanin, flavonoid dan aktivitas antioksidan. Fakultas Teknologi Pertanian, Universitas Semarang, Semarang.

Stankovic, M.S. Niciforovic, N., Mihailovic, V., Topuzovic, M. dan Solujic, S. (2012). Antioxidant activity, total phenolic content and flavonoid concentrations of different plant parts of Teucrium polium L. subsp. polium. Acta Societatis Botanicorum Poloniae .81: 117- 122.

Suryani, N. C., D.G.M. Permana, dan A.A.G.N. A. Jambe. 2015. Pengaruh Jenis Pelarut Terhadap Kandungan Total Flavonoid dan Aktivitas Antioksidan Ekstrak Daun Matoa (Pometia pinnata). Skripsi S1. Tidak dipublikasikan. Fakultas Teknologi Pertanian Universitas Udayana, Bali. 
Xu, B.J., dan S.K.C. Chang. 2007. A Comperative study on phenolic profiles and antioxidant activities of legumes as affectedby extraction solvents. Journal of Food Science. 72(2):159-166.

Widarta, I.W.R., dan I.W. Arnata. 2017. Ekstraksi komponen bioaktif daun alpukat dengan bantuan ultrasonik pada berbagai jenis dan konsentrasi pelarut. Jurnal AGRITECH. 37(2):148-157.

Yuswi, N.C.R. 2017. Ekstraksi antioksidan bawang dayak (Eleutherine bawang dayak (Eleutherine palmifolia) dengan metode Ultrasonic bath (kajian jenis pelarut dan lama ekstraksi). Jurnal Pangan dan Agroindustri. 5(1):71-79.

Zhang, L., Y. Shan, K. Tang, dan R. Putheti. 2009. Ultrasound-assisted extraction flavonoid of lotus (Nelumbo nuficera Gaertn) leaf and evaluation of its antifatigue activity. International Journal of Phisical Science. 4(8):418-422. 